\title{
Faktor-Faktor yang Berhubungan dengan Kejadian Kekurangan Energi Kronis (KEK) pada Ibu Hamil di Wilayah Kerja Puskesmas Krueng Barona Jaya Kabupaten Aceh Besar
}

\author{
Factors Related to The Occurrence of Chronic Energy Deficiency (CED) in \\ Pregnant Women at Work Area Health Center Jaya Krueng Barona District Of \\ Aceh \\ Rizky Swastika Renjani*1, ${ }^{1}$ Misra $^{2}$ \\ ${ }^{1,2}$ Program Studi Diploma IV Kebidanan Fakultas Ilmu Kesehatan Universitas Ubudiyah Indonesia \\ Jalan Alue Naga Desa Tibang Banda Aceh - Indonesia \\ *Korespondensi Penulis: rs.renjani@uui.ac.id
}

\begin{abstract}
Abstrak
Kejadian kelahiran premature dan BBLR disebabkan karena ibu hamil mengalami kurang gizi (kurang energi kronis/KEK, yang ditandai dengan lingkar lengan atas kurang dari $23,5 \mathrm{~cm}$. jumlah ibu hamil di wilayah kerja puskesmas Krueng Barona Jaya pada tahun 2016 berjumlah 347 orang yang mengalami sebanyak KEK 20 orang. Untuk mengetahui hubungan umur, pendidikan, paritas, jarak kehamilan dan penyakit dengan kejadian KEK pada ibu hamil.penelitian bersifat analitik dengan desain case control. Pengambilan sampel menggunakan tehnik purposive sampling dengan jumlah sampel 40 responden (20 responden sebagai kontrol dan 20 responden sebagai kasus).Pengumpulan data dilakukan pada tanggal 24 - 29 Juli 2017 pada ibu hamil di wilayah kerja puskesmas Krueng Barona Jaya Aceh Besar. Cara pengumpulan data dengan menggunakan lembar kuesioner, selanjutnya dilakukan uji chi-square dengan tingkat kepercayaan $95 \%$ dan batas kemaknaan $(\alpha=0,05)$. Umur memiliki risiko terhadap terjadinya KEK pada ibu hamil $(\mathrm{p}=0,003)(\mathrm{OR}=13,5)$, pendidikan memiliki risiko terhadap terjadinya di KEK pada ibu hamil $(\mathrm{p}=0,001)(\mathrm{OR}=13,2)$, paritas memiliki risiko terhadap terjadinya KEK pada ibu hamil $(\mathrm{p}=0,024)(\mathrm{OR}=6,0)$, jarak kehamilan memiliki terhadap terjadinya KEK pada ibu hamil dan penyakit infeksi juga memiliki risiko terhadap terjadinya KEK pada ibu hamil $(\mathrm{p}=0,000)(\mathrm{OR}=17,0)$. Umur, pendidikan, paritas, jarak kelahiran dan penyakit infeksi berisiko memberikan peluang terhadap KEK pada ibu hamil di wilayah kerja Puskesmas Krueng Barona Jaya Aceh Besar Tahun 2017.Diharapkan hasil penelitian ini dapat menjadi tolak ukur penilaian status gizi ibu hamil, sehingga diharapkan kedepannya petugas kesehatan mampu mendeteksi dini sehingga mampu meminimalisir angka kejadian KEK pada ibu hamil.
\end{abstract}

Kata kunci : umur, pendidikan, paritas, jarak kehamilan, kekurangan energi kronis

\section{Abstract}

The incidence of premature birth and low birth weight due to maternal malnutrition (chronic energy malnutrition/CED, which is characterized by upper arm circumference of less than $23.5 \mathrm{~cm}$. the number of pregnant women in the region of Krueng Barona Jaya health centers in 2016 amounted to 347 people who suffered as much as CED 20 people. To determine the relationship of age, education, parity, spacing pregnancies and disease with the incidence of maternal hamil.penelitian CED analytic with case control design. Sampling using purposive 
sampling technique with a sample of 40 respondents $(20$ respondents as a control and 20 respondents as the case) the data collection was carried out in 24 - Juni 29, 2017 in pregnant women at health centers working area Krueng Barona Jaya, Aceh Besar. The data collected by using questionnaire, then performed the chi-square test with a confidence level of $95 \%$ and the limit of significance $(\alpha=0.05)$. Age has a risk to the CED in pregnant women $(p=0.003)$ $(O R=13.5)$, educational risk to the occurrence of at CED in pregnant women $(p=0.001)$ $(O R=13.2)$, parity risk to the occurrence of CED in pregnant women $(p=0.024)(O R=$ 6.0), spacing pregnancies have against the SEZ in pregnant women and infectious diseases also have exposure to the CED in pregnant women $(p=0.000)(O R=17.0)$, Age, education, parity, birth spacing and the risk of infectious diseases provides an opportunity to CED in pregnant women in Puskesmas Krueng Barona Jaya, Aceh Besar Year 2017. Results of this study can be a benchmark for assessment of nutritional status of pregnant women, so expect future health workers able to detect early so as to minimize the incidence of CED in pregnant women.

Keywords: age, education, parity, spacing pregnancies, chronic energy deficiency

\section{PENDAHULUAN}

Gizi dalam masa kehamilan sangat penting.Selama kehamilan, terjadi penyesuaian metabolisme dan fungsi tubuh terutama dalam hal mekanisme dan penggunaan energi. Selain itu zat gizi yang terkandung dalam makanan akan diserap oleh janin untuk pertumbuhan dan perkembangannya selama di dalamuterus. Pada trimester pertama janin membutuhkan zat gizi berupa mikronutrien penting untuk pembentukan antara lain sistem saraf pusat dan organorgan vital (Rahmaniar, 2011).

Angka Kematian Bayi (AKB) mencapa 32 per 1000 kelahiran hidup. Jika dibandingkan dengan negara-negara anggota ASEAN, yaitu 4,6 kali lebih tinggi dari Malaysia, 1,3 kali lebih tinggi dari Filipina, dan 1,8 kali lebih tinggi dari Thailand. Beberapa penyebab kematian bayi dapat bermula dari masa kehamilan 28 minggu sampai hari ke-7 setelah persalinan (masa perinatal). Penyebab kematian bayi yang terbanyak adalah karena pertumbuhan janin yang lambat, kekurangan gizi pada janin, kelahiranprematur dan berat badan bayi lahir yang rendah, yaitu sebesar 38,85\% (Sutriani, 2015).

Pada tahun 2015 jumlah ibu hami 443 dan dengan KEK di Kabupaten Aceh Besar sebanyak 330 Wilayah kerja Puskesmas Ingin Jaya memiliki angka tertinggi kejadian KEK yaitu sebanyak 30 kasus, disusul Puskesmas Darussalam 24 kasus, Puskesmas Krueng Barona Jaya 24 kasus, Puskesmas Montasik 19 kasus, Puskesmas Kuta Baro 15 kasus, Puskesmas Leupung 12 kasus, Puskesmas Lampupok 7 kasus, Puskesmas Kuta Cot Glie 6 kasus, Puskesmas Ie Alang 6 kasus, Puskesmas Lhoknga 2 kasus, Puskesmas Indrapuri 2 kasus, 
Puskesmas Seulimum dan Puskesmas Lamteuba masing-masing 1 kasus (Profil Dinkes Aceh Besar, 2015).

Pada tahun 2016 terdapat 448 kasus ibu hamil dengan KEK yang tersebar di 27 Puskesmas di Kabupaten Aceh Besar dengan rincian sebagai berikut, Puskesmas Indrapuri dan Krueng Barona Jaya masing-masing 50 kasus, Puskesmas Baitussalam 39 kasus, Puskesmas Ingin Jaya 36 Kasus, Puskesmas Darul Imarah 34 kasus, Puskesmas Kuta Baro27 kasus, Puskesmas Lhong 26 kasus, Puskesmas Mesjid Raya 23 kasus, Puskesmas Lhoknga 21 kasus, Puskesmas Darussalam 16 kasus, Puskesmas Suka Makmur 15 kasus, Puskesmas Montasik 14 kasus, Puskesmas Seulimum 13 kasus, Puskesmas Lampupok dan Lampisang masing-masing 9 kasus, Puskesmas Lamteuba dan Kuta Malaka masing-masing 8 kasus, Puskesmas Leupung, Kuta Cot Glie dan sare masing-masing 7 kasus, Puskesmas Darul Imarah 5 kasus, Puskesmas Piyeung, Simpang Tiga dan Pulo Aceh masing-masing 4 kasus, Puskesmas Peukan Bada dan Blang Bintang 3 kasus dan Puskesmas Ie Alang dan Puskesmas Kota Jantho 0 kasus (Profil Dinkes, 2016).

Adapun faktor yang berpengaruh terhadap kejadian kurang gizi pada ibu hamil antara lain pengetahuan tentang gizi yang kurang, keterbatasan ekonomi, perilaku yang masih dipengaruhi oleh adat atau tradisi, pemenuhan makanan berdasarkan pada makanan kesukaan saja, pantangan pada makanan tertentu, tidakseimbang antara kebutuhan energi dengan intake makanan dan penyakit infeksi, sedangkan penyebab kurang gizi pada ibu hamil trimester pertama yang paling sering terjadi adalah mual muntah kehamilan (emesis gravidarum), penyakit infeksi, dan status gizi kurang pada prakonsepsi (Chomaria, 2012).

Berdasarkan hasil survei data awal yang dilakukan di wilayah kerja puskesmas Krueng Barona Jaya, diketahui jumlah ibu hamil pada tahun 2016 berjumlah 347 orang sedangkan yang mengalami KEK 20 orang dengan pengukuran lingkar lengan atas kurang dari 23,5.Hasil wawancara yang peneliti lakukan menunjukkan yang mengalami KEK memiliki umur ibu hamil yang lebih muda dari 20 tahun atau yang lebih atua dari 35 tahun dengan pendidikan yang rendah dan memiliki pekerjaan yang kurang menghasilkan uang yang banyak.

Penelitian ini untuk mengetahui faktor-faktor yang berhubungan dengan kejadian kekurangan energi kronis (KEK) pada ibu hamil di wilayah kerja Puskesmas Krueng Barona Jaya Kabupaten Aceh Besar Tahun 2017. 


\section{METODE PENELITIAN}

Penelitian ini merupakan penelitian yang bersifat Analitik, dengan menggunakan pendekatan Case Control yaitu rancangan yang mempelajari hubungan antara faktor paparan dan penyakit dengan cara membandingkan antara kelompok kasus dan kelompok kontrol berdasarkan status paparannya. Dalam hal ini penulis ingin mengetahui faktor-faktor yang berhubungan dengan kejadian Kekurangan Energi Kronis (KEK) Pada Ibu Hamil di wilayah Kerja Puskesmas Krueng Barona Jaya Kabupaten Aceh Besar Tahun 2017.

Penelitian telah dilaksanakan di wilayah kerja Puskesmas Krueng Barona Jaya Kabupaten Aceh Besar pada tanggal 24 - 29 Juli 2017. Populasi dalam penelitian ini adalah seluruh ibu hamil yang mengalami KEK dan tidak mengalami KEK di wilayah Kerja Puskesmas Krueng Barona Jaya Kabupaten Aceh Besar. Sampel dalam penelitian ini dibagi menjadi 2 kelompok, yaitu :

\section{Sampel Kasus}

Besar sampel dihitung dengan memanfaatkan rumus besar sampel uji hipotesis perbedaan 2 proporsi yaitu (Lameshow, 1997) dalam prinsip dan metode riset epidemiologi (Murti, 1997) :

$\mathrm{n}=\frac{\left\{Z 1-\alpha / 2 \sqrt{[2 P(1-P)]+Z 1-\beta \sqrt{[P 1(1-P 1)+P 2(1-P 2)\}^{2}}}\right.}{(P 1-P 2)^{2}}$

Keterangan :

$\mathrm{N}=$ Jumlah sampel minimal

Z1- $\alpha / 2=$ Nilai pada distribusi normal standar $(\alpha=0,05$ adalah 1,96$)$

Z1- $\beta=$ Nilai pada distribusi normal standar $(\beta=0,10$ adalah 0,84$)$

$\mathrm{P} 1=$ Proporsi subyek pada kelompok penyakit

$\mathrm{P} 2=$ Proporsi subyek pada kelompok bukan dengan penyakit

$\mathrm{P} 1=\frac{O R}{O R+1}$

$\mathrm{P}=(\mathrm{P} 1+\mathrm{P} 2) / 2$

$\mathrm{OR}=$ Odd Ratio

Dari persamaan di atas didasarkan pada perhitungan P2 dan OR hasil penelitian yang dilakukan peneliti terdahulu, di mana jumlah sampel setiap variabel dengan $\alpha=0,05$, perbandingan 1 kasus 1 kontrol dapat dihitung besar sampel minimal seperti tabel berikut:

Tabel 1. Rekapitulasi Nilai Odds Ratio Penelitian terdahulu

\begin{tabular}{|lr|l|l|l|l|}
\hline $\begin{array}{l}\text { Faktor-faktor } \begin{array}{r}\text { yang } \\
\text { berhubungan } \\
\text { kejadian KEK }\end{array} \\
\text { dengan }\end{array}$ & P2 & OR & N \\
\hline Umur & 0,89 & 0,52 & 7,73 & 22 \\
\hline Pendidikan & 0,72 & 0,44 & 3,27 & 35 \\
\hline
\end{tabular}


Maka :

\begin{tabular}{|l|c|c|c|c|}
\hline Paritas & 0,72 & 0,78 & 2,66 & 45 \\
\hline Jarak Kehamilan & 0,78 & 0,50 & 3,57 & 20 \\
\hline $\begin{array}{l}\text { Penyakit Infeksi pada } \\
\text { saat kehamilan }\end{array}$ & 0,76 & 0,41 & 2,56 & 30 \\
\hline
\end{tabular}

$\mathrm{P} 1=\frac{3,57}{3,57+1}$

$$
\begin{aligned}
& =0,78 \\
& =(\mathrm{P} 1+\mathrm{P} 2) / 2 \\
& =(0,78+0,50) / 2 \\
& =0,64
\end{aligned}
$$

$\mathrm{n}=\frac{\left\{Z 1-\alpha / 2 \sqrt{[2 P(1-P)]+Z 1-\beta \sqrt{[P 1(1-P 1)+P 2(1-P 2)\}^{2}}}\right.}{(P 1-P 2)^{2}}$

$\mathrm{n}=\frac{\left\{1,96 \sqrt{[2.0,64(1-0,64)]+0,84 \sqrt{[0,78(1-P 1)+0,5(1-0,5)\}^{2}}}\right.}{(0,78-0,50)^{2}}$

$\mathrm{n}=\frac{1,568}{0,0784}$

$\mathrm{n}=20$

$\mathrm{n}=$ minimal sampel 20

Berdasarkan hasil perhitungan di atas, maka diperoleh jumlah minimal sampel dalam penelitian ini adalah 20 orang.

Sampel kontrol adalah ibu hamil yang tidak mengalami KEK di wilayah kerja Puskesmas Krueng Barona Jaya.Penulis membuat perbandingan antara jumlah sampel kasus dan kontrol 1:1, sehingga jumlah sampel kontrol dalam penelitian ini adalah 20 responden. Jadi jumlah total sampel penelitian ini adalah 40 responden, yaitu 20 sampel kasus (Ibu hamil yang mengalami KEK) dan 20 sampel kontrol (Ibu hamil yang tidak mengalami KEK).

Data yang diperoleh langsung dari responden dengan mengukur LILA dan menyebarkan kuesioner. Data yang diperoleh dari instansi terkait seperti dinas kesehatan Kota Jantho dan data Puskesmas Krueng Barona JayaInstrumenmenggunakan adalah kuesioner. Pengolahan data dengan menggunakan komputer dapat dilakukan melalui tahap-tahap sebagai berikut Editing, Coding, Memasukkan Data (Data Entry), Pembersihan Data (Cleaning) dan analisa data menggunakan uji chiquare. 


\section{HASIL DAN PEMBAHASAN}

Tabel 2. Distribusi Frekuensi Umur, Pendidikan, Paritas, Jarak Kehamilan dan Penyakit Infeksi Pada Ibu Hamil di Wilayah Kerja Puskesmas Krueng Barona Jaya Aceh Besar Tahun 2017

\begin{tabular}{lcccc}
\hline & \multicolumn{2}{c}{ Kasus } & \multicolumn{2}{c}{ Kontrol } \\
\cline { 2 - 6 } & $\mathbf{n}$ & $\mathbf{\%}$ & $\mathbf{n}$ & $\boldsymbol{\%}$ \\
\hline Umur & & & & \\
$-<20$ tahun dan $>35$ tahun & 12 & 60 & 2 & 10 \\
$-20-35$ tahun & 8 & 40 & 18 & 90 \\
\hline Total & 20 & 100 & 20 & 100 \\
\hline Pendidikan & & & & \\
Rendah & 17 & 85 & 6 & 30 \\
Tinggi & 3 & 15 & 14 & 70 \\
\hline Total & 20 & 100 & 20 & 100 \\
\hline Paritas & & & & \\
- Berisiko & 12 & 60 & 4 & 20 \\
Tidak Berisiko & 8 & 40 & 16 & 80 \\
\hline Total & 20 & 100 & 20 & 100 \\
\hline Jarak Kehamilan & & & & \\
Berisiko & 14 & 70 & 4 & 20 \\
Tidak Berisiko & 6 & 30 & 16 & 80 \\
\hline Total & 20 & 100 & 20 & 100 \\
\hline Penyakit Infeksi & & & & \\
- Ada & 15 & 75 & 3 & 15 \\
Tidak Ada & 5 & 25 & 17 & 45 \\
\hline Total & 20 & 100 & 20 & 100 \\
\hline
\end{tabular}

Berdasarkan tabel 2 di atas menunjukkan bahwa dari 40 responden berumur $<20$ tahun dan > 35 tahun mengalami KEK yaitu sebanyak 12 responden (60\%), pendidikan rendah mengalami KEK yaitu sebanyak 17 responden $(85 \%)$, paritas berisiko mengalami KEK yaitu sebanyak 12 responden (60\%), jarak kehamilan berisiko mengalami KEK yaitu 14 responden $(70 \%)$ dan yang mengalami penyakit infeksi mengalami KEK yaitu 15 responden $(75 \%)$.

Tabel 3. Hubungan Umur dengan Kejadian Kekurangan Energi Kronis (KEK) Pada Ibu Hamil di Wilayah Kerja Puskesmas Krueng Barona JayaAceh Besar Tahun 2017

\begin{tabular}{ccccccc}
\hline \multirow{2}{*}{ Umur } & \multicolumn{4}{c}{ Kejadian KEK } & \multirow{2}{*}{$\mathbf{P}_{\text {value }}$} & \multirow{2}{*}{ OR } \\
\cline { 2 - 5 } & \multicolumn{2}{c}{ Kasus } & \multicolumn{2}{c}{ Kontrol } & & \\
\cline { 2 - 5 } & $\mathbf{f}$ & $\mathbf{\%}$ & $\mathbf{f}$ & $\boldsymbol{\%}$ & & \\
\hline$<20$ dan $>35$ tahun & 12 & 60 & 2 & 10 & 0,003 & 13,5 \\
$20-35$ tahun & 8 & 40 & 18 & 90 & & \\
\hline Total & 20 & 100 & 20 & 100 & & \\
\hline
\end{tabular}


Berdasarkan tabel di atas dapat dijelaskan bahwa kejadian KEK pada ibu hamil yang berumur $<20$ tahun dan $>35$ tahun lebih banyak terjadi pada kelompok kasus yaitu $60 \%$, sementara pada kelompok kontrol hanya $10 \%$. Hasil uji ststistik diperoleh nilai $\mathrm{OR}=13,5$ yang berarti bahwa ibu hamil yang berumur $<20$ tahun dan $>35$ tahun mempunyai peluang 13,5 kali lebih besar mengalami KEK dibandingkan yang berumur 20 - 35 tahun.

Tabel 4. Hubungan Pendidikan dengan Kejadian Kekurangan Energi Kronis (KEK) Pada Ibu Hamil di Wilayah Kerja Puskesmas Krueng Barona Jaya Aceh Besar Tahun 2017

\begin{tabular}{lcccccc}
\hline \multirow{2}{*}{ Pendidikan } & \multicolumn{9}{c}{ Kejadian KEK } & & \multirow{2}{*}{ OR } \\
\cline { 2 - 5 } & \multicolumn{2}{c}{ Kasus } & \multicolumn{2}{c}{ Kontrol } & polue & OR \\
\cline { 2 - 5 } & $\mathbf{f}$ & $\mathbf{\%}$ & $\mathbf{f}$ & $\mathbf{\%}$ & & \\
Rendah & 17 & 85 & 6 & 30 & 0,001 & 13,2 \\
Tinggi & 3 & 15 & 14 & 70 & & \\
\hline \multicolumn{1}{c}{ Total } & $\mathbf{2 0}$ & $\mathbf{1 0 0}$ & $\mathbf{2 0}$ & $\mathbf{1 0 0}$ & & \\
\hline
\end{tabular}

Berdasarkan tabel di atas dapat dijelaskan bahwa kejadian KEK pada ibu hamil yang berpendidikan rendah lebih banyak terjadi pada kelompok kasus yaitu 85\%, sementara pada kelompok kontrol hanya 30\%. Hasil uji ststistik diperoleh nilai OR =13,2 yang berarti bahwa ibu hamil yang berpendidikan rendah mempunyai peluang 13,2 kali lebih besar mengalami KEK dibandingkan yang berpendidikan tinggi.

Tabel 5. Hubungan Paritas dengan Kejadian Kekurangan Energi Kronis (KEK) Pada Ibu Hamil di Wilayah Kerja Puskesmas Krueng Barona JayaAceh Besar Tahun 2017

\begin{tabular}{ccccccc}
\hline \multirow{2}{*}{ Paritas } & \multicolumn{4}{c}{ Kejadian KEK } & \multirow{2}{*}{ p } & \multirow{2}{*}{ OR } \\
\cline { 2 - 5 } & \multicolumn{2}{c}{ Kasus } & \multicolumn{2}{c}{ Kontrol } & & \\
\cline { 2 - 5 } & $\mathbf{f}$ & $\mathbf{\%}$ & $\mathbf{f}$ & $\mathbf{\%}$ & & \multirow{2}{*}{0,024} \\
\cline { 2 - 5 } Berisiko & 12 & 60 & 4 & 20 & 0,024 & \\
Tidak berisiko & 8 & 40 & 16 & 80 & & \\
\hline Total & $\mathbf{2 0}$ & $\mathbf{1 0 0}$ & $\mathbf{2 0}$ & $\mathbf{1 0 0}$ & & \\
\hline
\end{tabular}

Berdasarkan tabel di atas dapat dijelaskan bahwa kejadian KEK pada ibu hamil dengan paritas berisiko lebih banyak terjadi pada kelompok kasus yaitu 60\%, sementara pada kelompok kontrol hanya 20\%. Hasil uji ststistik diperoleh nilai OR $=6,0$ yang berarti bahwa ibu hamil dengan paritas berisiko mempunyai peluang 6 kali lebih besar mengalami KEK dibandingkan yang paritas tidak berisiko. 
Tabel 6. Hubungan Jarak Kehamilan dengan Kejadian Kekurangan Energi Kronis (KEK) Pada Ibu Hamil di Wilayah Kerja Puskesmas Krueng Barona Jaya Aceh Besar Tahun 2017

\begin{tabular}{lcccccc}
\hline \multirow{2}{*}{ Jarak Kehamilan } & \multicolumn{9}{c}{ Kejadian KEK } & & \multirow{2}{*}{ Ko } \\
\cline { 2 - 5 } & \multicolumn{2}{c}{ Kasus } & \multicolumn{2}{c}{ Kontrol } & & \\
\cline { 2 - 5 } & $\mathbf{f}$ & $\mathbf{\%}$ & $\mathbf{f}$ & $\mathbf{\%}$ & & \\
\hline Berisiko & 14 & 70 & 4 & 20 & 0,004 & 9,3 \\
Tidak berisiko & 6 & 30 & 16 & 80 & & \\
\cline { 1 - 5 } \multicolumn{1}{c}{ Total } & $\mathbf{2 0}$ & $\mathbf{1 0 0}$ & $\mathbf{2 0}$ & $\mathbf{1 0 0}$ & & \\
\hline
\end{tabular}

Berdasarkan tabel di atas dapat dijelaskan bahwa kejadian KEK pada ibu hamil dengan jarak kehamilan berisiko lebih banyak terjadi pada kelompok kasus yaitu 70\%, sementara pada kelompok kontrol hanya $20 \%$. Hasil uji ststistik diperoleh nilai $\mathrm{OR}=9,3$ yang berarti bahwa ibu hamil dengan jarak kehamilan berisiko mempunyai peluang 9,3 kali lebih besar mengalami KEK dibandingkan dengan jarak kehamilan tidak berisiko.

Tabel 7. Hubungan Penyakit Infeksi dengan Kejadian Kekurangan Energi Kronis (KEK) Pada Ibu Hamil di Wilayah Kerja Puskesmas Krueng Barona Jaya Aceh Besar Tahun 2017

\begin{tabular}{|c|c|c|c|c|c|c|}
\hline \multirow{3}{*}{$\begin{array}{c}\text { Penyakit } \\
\text { Infeksi }\end{array}$} & \multicolumn{4}{|c|}{ Kejadian KEK } & \multirow[b]{2}{*}{$\mathbf{p}_{\text {value }}$} & \multirow[b]{2}{*}{ OR } \\
\hline & \multicolumn{2}{|c|}{ Kasus } & \multicolumn{2}{|c|}{ Kontrol } & & \\
\hline & $\mathbf{f}$ & $\%$ & $\mathbf{f}$ & $\%$ & \multirow{4}{*}{0,000} & \multirow{4}{*}{17,0} \\
\hline Ada & 15 & 75 & 3 & 15 & & \\
\hline Tidak Ada & 5 & 25 & 17 & 85 & & \\
\hline Total & 20 & 100 & 20 & 100 & & \\
\hline
\end{tabular}

Berdasarkan tabel di atas dapat dijelaskan bahwa kejadian KEK pada ibu hamil yang mengalami penyakit infeksi lebih banyak terjadi pada kelompok kasus yaitu 75\%, sementara pada kelompok kontrol hanya $15 \%$. Hasil uji ststistik diperoleh nilai OR = 17,0 yang berarti bahwa ibu hamil yang mengalami penyakit infeksi mempunyai peluang 9,3 kali lebih besar mengalami KEK dibandingkan dengan yang tidak mengalami penyakit infeksi.

\section{Pembahasan}

1. Hubungan Umur dengan Kejadian KEK Pada Ibu Hamil

Berdasarkan tabel 2 menunjukkan bahwa kejadian KEK pada ibu hamil yang berumur $<20$ tahun dan $>35$ tahun lebih banyak terjadi pada kelompok kasus yaitu 60\%, sementara pada kelompok kontrol hanya 10\%. Hasil uji ststistik diperoleh nilai $\mathrm{OR}=13,5$ yang berarti bahwa ibu hamil yang berumur berisiko mempunyai peluang 13,5 kali lebih besar mengalami KEK dibandingkan yang berumur 20 - 35 tahun. 
Hal ini sejalan dengan penelitian Marlapan (2013) di wilayah kerja Puskesmas Tuminting Kota Manado menunjukkan bahwa nilai $\mathrm{p}=0,005$ dan nilai $\mathrm{OR}=7,73$, yang artinya ibu hamil dengan umur berisiko 7 kali lipat lebih beresiko mengalami KEK daripada ibu hamil dengan umur berisiko yang tidak mengalami KEK.salah satu faktor pendorong para ibu hamil diusia muda adalah karena ibu menikah di umur yang terlalu muda, sehingga pada saat ibu memasuki masa kehamilan, kondisi alat reproduksinya secara biologis belum siap dan secara psikis juga belum matang, karena dalam masa pertumbuhan tubuh menbutuhkan asupan nutrisi dalam jumlah banyak, sehingga kebutuhan tubuh ibu dan kebutuhan janin tidak seimbang bahkan terjadi kekurangan gizi, begitu juga halnya pada ibu yang hamil pada usia tua, tubuh membutuhkan energi lebih banyak karena sistem tubuh yang mulai lemah.

Penelitian Mahirawati (2014) tentang faktor-faktor yang berhubungan dengan kekurangan energykronis pada ibu hamil di kecamatan Kamoning dan Tambelangan Kabupaten Sampang Jawa Timur menunjukkan bahwa nilai $\mathrm{p}=0,004$ dan nilai $\mathrm{OR}=$ 3,112 , yang artinya ibu hamil dengan umur berisiko 3 kali lipat lebih beresiko mengalami KEK daripada ibu hamil dengan umur berisiko yang tidak mengalami KEK, maka umur merupakan salah satu faktor penting dalam proses kehamilan hingga persalinan, karena kehamilan pada ibu yang berumur muda menyebabkan terjadinya kompetisi makanan antara janin dengan ibu yang masih dalam masa pertumbuhan.

Umur merupakan faktor penting dalam proses kehamilan sampai persalinan, karena kehamilan ibu yang berumur muda menyebabkan terjadinya kompetisi makanan antara janin dengan ibu yang masih dalam masa pertumbuhan. Ibu yang berumur kurang dari 20 tahun memiliki risiko KEK yang lebih tinggi. Semakin muda usia ibu kurang dari 20 tahun dan lebih tua usia ibu dari 35 tahun yang sedang hamil akan berpengaruh terhadap kebutuhan gizi yang diperlukan akan menyebabkan mengalami KEK. Pada umur muda diperlukan tambahan gizi yang banyak karena selain digunakan untuk pertumbuhan dan perkembangan diri sendiri, juga harus berbagi dengan janin yang sedang dikandungnya.Sedangkan pada umur tua diperlukan energi yang besar pula karena fungsi organ yang melemah dan diharuskan untuk bekerja maksimal, maka perlu adanya tambahan energi yang cukup sebagai pendukung kehamilan yang sedang berlangsung. Sehingga usia yang paling baik adalah lebih dari 20 tahun sampai dengan 35 tahun (Helena, 2013). 
Wanita yang mengalami kehamilan di usia remaja 15-19 tahun merupakan salah satu kelompok yang paling rawan terhadap masalah gizi terutama KEK. Kehamilan yang tejadi pada usia remaja disertai dengan kondisi KEK merupakan kehamilan yang berisiko tinggi karena terjadi kompetisi nutrisi pada ibu hamil usia remaja dengan janin yang di kandungnya. Pada usia 15-19 tahun remaja masih di dalam proses pertumbuhan sedangkan nutrisi yang di perolehnya selain di gunakan untuk proses pertumbuhan remaja itu sendiri jaga digunakan pertumbuhan janin yang di kandungnya (Kepmenkes RI, 2012).

Asumsi peneliti, ibu dengan umur berisiko lebih banyak mengalami KEK, karena pada pada usia $<20$ tahun ibu merupakan masih dalam masa pertumbuhan dan sekaligus dalam keadaan hamil jadi ibu membutuhkan gizi dan nutrisi lebih banyak, tapi kebanyakan orang salah memaknainya, ibu muda dianggap masih kuat, energik dan dalam masa pertumbuhan, jadi ketika hamil banyak ibu yang tidak mau minum susu, makan semau mereka tanpa memperhatikan nilai gizi, tidak mau minum tablet tambah darah, sehingga ibu rentan sekali mengalami KEK karena metabolisme yang tinggi masa pertumbuhan dan kehamilan tidak diimbangi dengan asupan nutrisi yang kurang seimbang. Begitu juga halnya dengan ibu yang hamil pada usia $>35$ tahun ibu mengalami kekurangan gizi karena selama hamil ibu makan seperti biasa saat belum hamil dan bahkan pada trimester 1 ibu tidak nafsu makan sehingga kebutuhan gizi yang dibutuhkan tidak terpenuhi untuk kehamilan dan masa usia > 35 tahun ini juga merupakan usia yang berisiko mengalami KEK karena pada usia ini, tubuh bermetabolisme lebih tinggi karena karena sistem tubuh yang mulai lemah, jadi apabila asupan gizi ibu kurang maka akan rentan sekali terjadi KEK karena terjadi ketidakseimbangan pemasukan dan pengeluaran gizi maupun energi

2. Hubungan Pendidikan dengan Kejadian KEK Pada Ibu Hamil

Berdasarkan tabel 3 menunjukkan bahwa kejadian KEK pada ibu hamil yang berpendidikan rendah lebih banyak terjadi pada kelompok kasus yaitu 85\%, sementara pada kelompok kontrol hanya 30\%. Hasil uji ststistik diperoleh nilai OR =13,2 yang berarti bahwa ibu hamil yang berpendidikan rendah mempunyai peluang 13,2 kali lebih besar mengalami KEK dibandingkan yang berpendidikan tinggi. 
Penelitian Mahirawati (2014) tentang faktor-faktor yang berhubungan dengan kekurangan energi kronis pada ibu hamil di kecamatan Kamoning dan Tambelangan Kabupaten Sampang Jawa Timur menunjukkan bahwa nilai $\mathrm{p}=0,000$ dan nilai $\mathrm{OR}=2,33$, yang berarti bahwa ibu hamil yang berpendidikan rendah mempunyai peluang 2 kali lebih besar mengalami KEK dibandingkan yang berpendidikan tinggi. Pendidikan ibu hamil tinggi dengan daya beli yang rendah mengakibatkan kebutuhan gizi ibu selama hamil baik dari segi kualitas mapun kuantitas belum terpenuhi, akhirnya ibu mengalami KEK.Masalah KEK pada ibu hamil juga terjadi pada ibu hamil yang berpendidikan tinggi karena ketidaktahuan dan kurangnya informasi tentang kesehatan dan gizi yang memadai.

Pendidikan adalah pendidikan formal yang di tempuh oleh ibu hamil sampai dengan mendapatkan STTB. Tingkat pendidikan juga dapat mempengaruhi seseorang dalam memahami informasi yang diterima, dimana ibu yanga berpendidikan tinggi lebih mudah mengerti tentang informasi yang dibutuhkan oleh petugas kesehatan baik dalam bentuk penyuluhan langsung, media massa, media elektronik maupunposter sehingga mereka akan bertindak sesuai dengan informasi terutama dalam mengkonsumsi makanan yang cukup mengandung zat sehingga tidak terjadi resiko kekurangan gizi pada saat hamil maupun bersalin ( Helena, 2013).

Tingkat pendidikan dapat di ketahui bahwa pada ibu yang tidak lulus SD/SMP sangat banyak mengalami KEK karena dengan pengetahuan yang kurang dapat mempengaruhi ibu prilaku konsumsi dan asupan makanan sedang dengan ibu yang lulus SMA/PT cenderung tidak mengalami KEK dengan tingkat pendidikan ibu yang tinggi ibu dapat mengosumsi asupan makanan yang bergizi agar dapat mencakup bagi ibu dan bayinya (Helena, 2013).

Asumsi Peneliti, ibu yang berpendidikan rendah dan menengah lebih banyak mengalami KEK karena ibu kurang paham akan kandungan zat gizi dalam makanan, seberapa besar yang dibutuhkan kehamilannya, cara pengolahan makanan sehingga nilai gizi makanan ibu menjadi berkurang bahkan hilang dan kadang ibu hanya makan makanan yang itu-itu saja, hanya makanan yang ia mau dengan anggapan yang penting mau makan dan tidak selera, sehingga kebutuhan nutrisi dan gizinya tidak terpenuhi sehingga ibu mengalami KEK. 
3. Hubungan Paritas dengan Kejadian KEK pada Ibu Hamil

Berdasarkan tabel 4 menunjukkan bahwa kejadian KEK pada ibu hamil dengan paritas berisiko lebih banyak terjadi pada kelompok kasus yaitu 60\%, sementara pada kelompok kontrol hanya $20 \%$. Hasil uji ststistik diperoleh nilai OR $=6,0$ yang berarti bahwa ibu hamil dengan paritas berisiko mempunyai peluang 6 kali lebih besar mengalami KEK dibandingkan yang paritas tidak berisiko.

Hal ini sejalan dengan penelitian Setiawan (2016) di Puskesmas Jagir yang menunjukkan $p=0,001(\mathrm{OR}=2,66)$, bahwa ibu dengan kehamilan paritas tinggi 2 kali lebih berisiko terkena KEK dibandingkan ibu dengan paritas rendah. Paritas yangtermasuk dalam faktor resiko tinggidalam kehamilan adalahgrademultipara, dimana hal ini dapatmenimbulkan keadaan mempengaruhioptimalisasi ibu maupun janin padakehamilan yang dihadapi.Dapatdisimpulkan kalau paritas yang tidaklebih dari 4 tidak beresiko mengalami gangguan, sehingga dalam penelitian ini dapat menyimpulkan nullipara dan primipara tidak termasuk dalam resikotinggi kehamilan.

Penelitian Setyaningrum (2014) tentang analisis faktor-faktor yang mempengaruhi kejadiana kekurangan energi kronis (KEK) pada ibu hamildi wilayah puskesmas Wedi Klaten menunjukkan bahwa nilai $\mathrm{p}=0,000$ dan nilai $\mathrm{OR}=5,662$, yang berarti bahwa kehamilan paritas tinggi 5 kali lebih berisiko terkena KEK dibandingkan ibu dengan paritas rendah. Paritas yangtermasuk dalam faktor resiko tinggidalam kehamilan adalah grademultipara, di mana hal ini dapat menimbulkan keadaan mempengaruhi optimalisasi ibu maupun janin pada kehamilan yang dihadapi. Dapat disimpulkan kalau paritas yang tidak lebih dari 4 tidak beresiko mengalami gangguan Paritas yang termasuk dalam faktor resiko tinggidalam kehamilan adalah grademultipara, dimana hal ini dapat menimbulkan keadaan mempengaruhi optimalisasi ibu maupun janin pada kehamilan yang dihadapi.

Paritas adalah jumlah kehamilan yang menghasilkan janin hidup, bukan jumlah janin yang dilahirkan. Paritas yang tinggi akan berdampak pada timbulnya berbagai masalah kesehatan baik bagi ibu maupun bayi yang dilahirkan. Ibu tidak memperoleh kesempatan untuk memperbaiki tubuhnya sendiri karena ibu memerlukan energi yang cukup untuk memulihkan keadaan setelah melahirkan anaknya. Mengandung kembali akan menimbulkan masalah gizi bagi ibu dan janin/bayi berikut yang dikandung. Kehamilan yang berulang dalam waktu singkat akan menguras cadangan zat gizi ibu 
sehingga ibu dengan paritas tinggi (berisiko) akan lebih rentan mengalami KEK (Arisman, 2010).

Asumsi peneliti ibu dengan paritas berisiko (primigravida dan grandenmultigravida) lebih banyak mengalami KEK karena ibu hamil pertama cenderung tidak memiliki pengalaman, jadi ibu lebih fokus pada apa yang ia rasa, hanya mau makan apa yang ibu mau, makan seadanya, tanpa mempertimbangkan kebutuhan gizinya, tanpa memikirkan efek dari kekurangan gizi (KEK) yang ibu alami nantinya yang dapat membahayakan bayinya. Ibu dengan grandenmultigravida juga banyak yang mengalami KEK karena dengan banyaknya beban dan tanggung jawab ibu, ibu menjadi kurang fokus dengan kesehatannya sendiri dan dengan pengalaman ibu pada kehamilan sebelumnya yang ibu rasa aman, padahal pada kehamilan ini umur ibu juga bertambah dan metabolisme tubuh ibu juga meningkat namun ibu tidak menyadari dan tidak memperbaiki pola konsumsi gizinya sehingga ibu mengalami KEK pada kehamilan ini.

4. Hubungan Jarak Kehamilan dengan Kejadian KEK Pada Ibu Hamil

Berdasarkan tabel 5 menunjukkan bahwa kejadian KEK pada ibu hamil dengan jarak kehamilan berisiko lebih banyak terjadi pada kelompok kasus yaitu 70\%, sementara pada kelompok kontrol hanya 20\%. Hasil uji ststistik diperoleh nilai OR = 9,3 yang berarti bahwa ibu hamil dengan jarak kehamilan berisiko mempunyai peluang 9,3 kali lebih besar mengalami KEK dibandingkan dengan jarak kehamilan tidak berisiko.

Hal ini sejalan dengan peneltian Yuliastuti (2014) di wilayah kerja Puskesmas Sungai Bilu Bnajarmasin, menunjukkan bahwa nilai signifikansi jarak kehamilan dengan kejadian KEK $(\mathrm{p}=0,003)(\mathrm{OR}=3,57)$. Apabila keluarga dapat mengatur jarak antara kehamilan lebih dari 2 tahun maka anak akan memiliki probabilitas hidup lebih tinggi dan kondisi anaknya lebih sehat dibanding anak dengan jarak kehamilan dibawah 2 tahun. Jarak kehamilan dan melahirkan yang terlalu dekat akan menyebabkan kualitas janin/anak yang rendah dan juga akan merugikan kesehatan ibu. Ibu tidak memperoleh kesempatan untuk memperbaiki tubuh-nya sendiri (ibu memerlukan energi yang cukup untuk memulihkan keadaan setelah melahirkan anaknya). Dengan mengandung kembali maka akan menimbulkan masalah gizi ibu dan janin/ bayi berikut yang dikandung.

Penelitian Handayani (2011) di Puskesmas Wedi Klaten menunjukkan bahwa $\mathrm{p}=$ $0,004(\mathrm{p}<0,05)(\mathrm{OR}=5,499)$, jarak melahirkan yang terlalu dekat akan menyebabkan ibu 
tidak memperoleh kesempatan untuk memperbaiki tubuhnya sendiri dimana ibu memerlukan energi yang cukup untuk memulihkan keadaan setelah melahirkan anaknya.

Penelitian Ardani (2015) tentang faktor-faktor yang berhubungan kejadian KEK padaibu hamil di BPM Ny. Sri Widyaningsih Am.Keb di desa Lemahireng Kabupaten Bawen Kabupaten Semarang menunjukkan bahwa ada hubungan jarak kehamilan dengan kejadian KEK pada ibu hamil ( $\mathrm{p}=0,002$ dan $\mathrm{OR}=4,112)$. untuk menjaga kesehatan ibu dan anak sebaiknya jarak antara kehamilan tidak kurang dari 2 tahun. Jadi, ibu memerlukan waktu setidaknya 2 tahun untuk memulihkan kesehatannya sebelum hamil lagi.

Jarak kehamilan sangat berpengaruh terhadap kejadian KEK pada saat kehamilan yang berulang dalam waktu singkat akan menguras cadangan zat gizi ibu. Selain itu, ibu yang hamil dalam jarak kurang dari 2 tahun setelah melahirkan sebelumnya mempunyai resiko melahirkan prematur dan bagi bayi akan mengalami berat lahir yang rendah. Wanita hamil menjadi salah satu kelompok yang rentan terhadap masalah gizi mempunyai resiko lebih besar terhadap kejadian KEK selama kehamilan (Surasih, 2015).

Pengaturan jarak kehamilan dimaksudkan agar tubuh ibu memiliki cukup waktu untuk memulihkan diri. Jika jarak kehamilan terlalu dekat, kesehatan ibu akan menurun karena tubuh tidak sempat kembali seperti kondisi semula. Masalah gizi yang timbul kemudian dapat memengaruhi kesehatan janin yang dikandung.Ibu membutuhkan energi yang cukup untuk memulihkan keadaan tubuhnya pasca melahirkan. Sementara itu, kehamilan meningkatkan kebutuhan ibu akan energi dan zat gizi (Yuliastuti, 2014).

Asumsi Peneliti, ibu dengan jarak kehamilan $<2$ tahun lebih banyak mengalami KEK karena banyak ibu dalam kehamilannya ini tanpa ada perencanaan dan ibu tidak tahu bahwa dirinya telah hamil (hingga mencapai usia kehamilan 3 bulan), karena ibu belum mendapatkan haid dari setelah masa nifas, dan disisi lain karena ketidaktahuannya tersebut ibu juga masih menyusui, sehingga tidak ada keseimbangan antara asupan nutrisi dengan kebutuhan ibu sehingga ibu mengalami KEK.

5. Hubungan Penyakit Infeksi dengan Kejadian KEK Pada Ibu Hamil

Berdasarkan tabel 6 menunjukkan bahwa kejadian KEK pada ibu hamil yang mengalami penyakit infeksi lebih banyak terjadi pada kelompok kasus yaitu 75\%, sementara pada kelompok kontrol hanya $15 \%$. Hasil uji ststistik diperoleh nilai OR = 
17,0 yang berarti bahwa ibu hamil yang mengalami penyakit infeksi mempunyai peluang 9,3 kali lebih besar mengalami KEK dibandingkan dengan yang tidak mengalami penyakit infeksi.

Hal ini sejalan dengan penelitian Hidayati (2011) di Puskesmas Ciputat Tangerang Selatan, bahwa hasil uji chi-square di peroleh nilai p-value $=0,046$. Hasil ini menyatakan bahwa ada hubungan antara penyakit infeksi dengan terjadinya KEK pada ibu hamil (OR $=2,56)$. Pengaruh penyakitinfeksidengan KEK tergantung dari besarnya dampak yang ditimbulkan, jika infeksi masih akut dan derajat infeksinya masih rendah tidak terlalu berpengaruh terhadap status gizi ibu hamil. Sebaliknya jika infeksi sudah kronis dan berlangsung lama akan dapat mempengaruhi status gizi ibu. Dalam penelitian ini, infeksi masih rendah jadi tidak terlalu berpengaru terhadap status gizi ibu hamil.

Penelitian Herawati (2013) tentang Faktor-faktor yang berhubungan dengan kejadian KEK pada ibu hamil di Puskesmas Jalaksana Kuningan menyatakan bahwa ada hubungan antara penyakit infeksi dengan terjadinya KEK pada ibu hamil $(\mathrm{p}=0,002, \mathrm{OR}=$ 2,56). Ibu hamil yang sedang sakit, terutama mengalami penyakit infeksi, maka metabolisme tubuhnya akan meningkat, sehingga tubuh akan membutuhkan energi lebih yang diperoleh dari makanan. Karena ibu yang dakit dan kondisi tubuh lemah biasanya dipengaruhi oleh nafsumakan yang menurun sehingga asupan makanan yang seharusnya diberikan tidakdapat tercukupi sehingga menyebabkan penurunan berat badan.

Dalam jurnal Malnutrition and Infection : Complex Mechanisms and Global Impactsoleh Schaible, et.al (2012) disebutkan penelitian di Kenya yang menemukan hubungan signifikan antara penyakit infeksi dengan lingkar lengan atas dan serum albumin. Selain itu, dalam jurnal Malnutrition and Pregnancy Wastage In Zambia oleh Wamie, data survey status gizi FAO menunjukkan 90,5\% ibu hamil menderita infeksi. Penyakit infeksi merupakan faktor yang mempengaruhi kesehatan dan keselamatan ibu. Status gizi kurang akan meningkatkan kepekaan ibu terhadap risiko terjadinya infeksi, dan sebaliknya infeksi dapat meningkatkan risiko kurang gizi bahkan kematian (Achadi, 2010).

Penyakit infeksi dapat bertindak sebagai pemula terjadinya kurang gizi sebagai akibat menurunnya nafsu makan, adanya gangguan penyerapan dalam saluran pencernaan atau peningkatan kebutuhan zat gizi oleh adanya penyakit.Kaitan penyakit infeksi dengan keadaan gizi kurang merupakan timbal balik, yaitu hubungan sebab akibat.Penyakit 
infeksi dapat memperburuk keadaan gizi dan keadaan gizi yang jelek dapat mempermudah infeksi, penyakit infeksi terkait status gizi yaitu TB, diare, dan malaria (Supariasa, 2010).

Asumsi peneliti, ibu yang menderita penyakit infeksi lebih banyak menderita KEK, karena ibu yang sakit karena infeksi, mengalami keluhan tidak nafsu makan bahkan ada yang mengalami muntah, sehingga tidak terpenuhi kebutuhan gizi ibu selama hamil dan daya tahan tubuh ibu menurun dan menyebabkan ibu KEK.

\section{KESIMPULAN}

Berdasarkan hasil penelitian yang dilakukan pada 40 responden, yaitu 20ibu hamil (50\%) yang mengalami KEK sebagai kasus dan 20ibu hamil (50\%) yang tidak mengalami KEK sebagai kontrol, maka diperoleh :

1. Ibu hamil yang berumur $<20$ tahun dan $>35$ tahun mempunyai peluang 13,5 kali lebih besar mengalami KEK dibandingkan yang berumur 20 - 35 tahun

2. Ibu hamil yang berpendidikan rendah mempunyai peluang 13,2 kali lebih besar mengalami KEK dibandingkan yang berpendidikan tinggi.

3. Ibu hamil dengan paritas berisiko mempunyai peluang 6 kali lebih besar mengalami KEK dibandingkan yang paritas tidak berisiko.

4. Ibu hamil dengan jarak kehamilan berisiko mempunyai peluang 9,3 kali lebih besar mengalami KEK dibandingkan dengan jarak kehamilan tidak berisiko.

5. Ibu hamil yang mengalami penyakit infeksi mempunyai peluang 9,3 kali lebih besar mengalami KEK dibandingkan dengan yang tidak mengalami penyakit infeksi.

\section{SARAN}

Puskesmas Krueng Barona Jaya diharapkan dapatmeningkatkan pengetahuan ibuhamil mengenai makanan yangbergizi dengan melakukanpenyuluhan maupun konseling gizi pada saat kunjungan antenatal, sehingga dapatmengurangi kejadian KEK diwilayah Puskesmas Krueng Barona Jaya.

\section{DAFTAR PUSTAKA}

Hidayat, F. 2011.Hubungan Antara Pola Konsumsi, Penyakit Infeksi, dan Pantang Makanan terhadap Risiko Kurang Energi Kronis (KEK) pada Ibu Hamil di Puskesmas Ciputat Kota Tangerang Selatan Tahun 2011.Skripsi. Program Studi Ilmu Kesehatan Masyarakat. Universitas Islam Negeri Syarif Hidayatullah. Jakart 
Helena. 2013. Buku Saku Gizi Dan Kesehatan Reproduksi. EGC : Jakarta

Kemenkes.2012. Pedoman Pelayanan Antenatal Terpadu. Jakarta

Marlapan, S. (2013).hubungan umur dengan status gizi pada ibu hamil di wiayah kerja Puskesmas Tuminting Kec, Tumnting Kota Manado. ejournal keperawatan (e-Kp) Volume 1. Nomor 1.Agustus 2013. Program Studi Ilmu Keperawatan Fakultas Kedokteran Universitas Sam Ratulangi Manado

Marlenywati.2010. Risiko KEK pada Ibu Hamil Remaja di Kota Pontianak Tahun 2010.Tesis. FKM UI. Depok

Mulyaningrum. 2013. Faktor-Faktor yang Berhubungan dengan Risiko Kurang Energi Kronis (KEK) pada Ibu Hamil di Provinsi DKI Jakarta (Analisis Data Riskesdas 2007). Skripsi. FKM UI

Profil Kesehatan Aceh (2015). Dinas Kesehatan Aceh Bidang Program dan Pelaporan. Cetakan Tahun 2016

Profil Kesehatan Indonesia (2015). Dinas Kesehatan Aceh Bidang Program dan Pelaporan. Cetakan Tahun 2016

Rahmaniar. 2011. Ilmu Gizi Untuk Praktisi Kesehatan. Graha Ilmu:Yogyakarta

Setiawan. 2016. Hubungan paritas dengan Kejadian KEKpada ibu hamil di Puskesmas Jagir. Jurnal Berkala Epidemiologi, Vol. 4, No. 1 Januari 2016: 100-112. Departemen Epidemiologi Fakultas Kesehatan Masyarakat Universitas Airlangga Surabaya, Jawa Timur

Sulistyonin.2012. Kesehatan Ibu dan Anak. Graha Ilmu : Yogyakarta

Supariasa.2010. Penilaian Status Gizi.EGC : Jakarta

Sutriani, 2015.Pertumbuhan Bayi dengan Berat Badan Lahir Rendah. PT. Gramedia Pustaka Umum : Jakarta

Yuliastuti, E. 2014.Faktor-Faktor yang berhubungan dengan Kekurangan Energi Kronis (KEK) pada ibu hamil di wilayah kerja Puskesmas Sungai Bilu Banjarmasin.Jurnal Kesehatan, Vol 1 No.2, Desember 2014, hal 72-76. Poltekkes Kemenkes Banjarmasin 